\title{
INTERNAL DEVELOPMENT DETERMINANTS OF POLISH \\ COMPANIES IN THE USA: TRADITIONAL INDUSTRIES VS. NEW TECHNOLOGIES
}

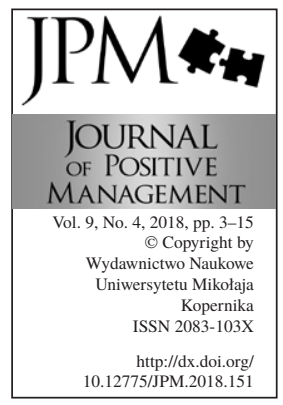

Magdalena Kuczmarska

\author{
Nicolaus Copernicus University in Torun, Faculty of Economic Sciences \\ and Management, Torun, Poland \\ e-mail: mkuczmarska@umk.pl
}

\begin{abstract}
Purpose: The purpose of the study was to identify the internal development determinants of Polish companies in the USA, considering the character of their activity, i.e. splitting them into two business sectors - traditional industries and new technologies.
\end{abstract}

Methodology: The research has been conducted by sending by post and e-mail a standardised questionnaire to Polish companies that have undertaken foreign direct investment in the USA. As a result, 19 properly filled survey questionnaires were returned.

Findings: The findings of the research indicated that Polish companies see major determinants of development in the USA in internal factors, including applied technology, innovative products/ services, organisation of production processes/services and management skills. Slight differences in the answers of companies representing both groups (traditional industries and new technologies) mainly concerned the strength of impact of particular assets. For companies in the new technologies group, most important growth determinants were, above all, used technology and innovation of products/services, while companies operating in traditional industries found the strongest positive impact in leadership, competences of the management staff and organisation culture.

Implications: Both the research results and the very fact of involvement in foreign investment in such competitive environment demonstrate that Polish companies are aware of the strength of their assets. Just as enterprises from the developed countries, they benefit from ownership advantages on foreign markets. These are not, however, cost advantages attributed to companies from the emerging markets in the subject literature, but those perceived as the domain of the companies from the developed countries.

Originality: This paper concerns a still insufficiently defined problem of foreign direct investment of companies from mid-range emerging economies in developed countries.

Keywords: foreign direct investment, internationalisation, internal development determinants, foreign subsidiaries, Central and Eastern Europe

Paper type: Research paper 
INTERNAL DEVELOPMENT DETERMINANTS

Magdalena Kuczmarska

Figure 1. Number of foreign entities with the participation of Polish capital in the USA and their growth dynamics (year 2008=100\%)

Source: own calculations based on Statistics Poland.

\section{Introduction}

In the age of rapid internationalisation, capital involvement of companies in form of foreign direct investment (FDI) seems a natural way to grow. This path is more and more frequently followed also by Polish enterprises. In the recent decade, the number of foreign businesses with Polish capital participation increased significantly - from roughly 2.5 thousand in 2008 to almost 4 thousand in 2017 (Statistics Poland, 2016; 2019). In the last year of that period, business entities from Poland had shares in foreign businesses located in 116 countries, but half of them were based in seven countries neighbouring Poland, so in a very close environment in terms of geography and culture. Capital investments in nonEuropean countries concerned a relatively small group of companies.

USA has a special place among countries outside Europe in which Polish capital is invested. According to the Statistics Poland data (as at the end of 2017), 147 entities with Polish capital were running business in that country, which was $3.7 \%$ of all companies with Polish caital abroad. That group might seem small, but the dynamic increase in the number of businesses with Polish capital in the USA is noteworthy, being twice as high as the rate of increase in the total number of foreign entities with Polish capital (Figure 1).

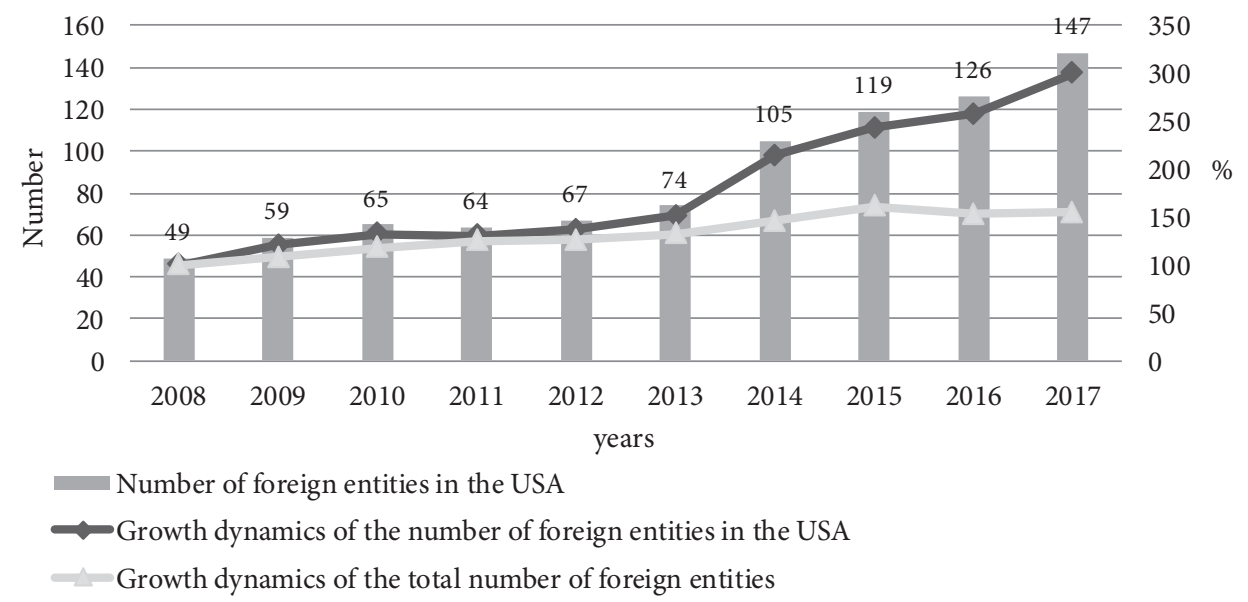

Companies with share of Polish equity operating on the American market are quite varied. Beside large manufacturing or services enterprises, following the traditional path of internationalisation, for which the USA is just another place on their route of foreign expansion, investment activity in that country is also seen among companies with relatively small experience in international operations, that belong to the new technology sector. It could be supposed that investment 
activity of the latter, manifested in allocation of their businesses in innovative ecosystems, such as the Silicon Valley, had a crucial impact on the number of entities with Polish capital in the USA. It is worth noting in this context that the rapid increase in their number, recorded in 2014, could be related with intensified government support for new businesses in the technology sector. As part of the mobilisation activities in 2013, an acceleration office was launched in the Silicon Valley, being the first Polish governmental "bridge organisation" (Pietrasieński, 2014).

What must be considered is that entering the American market is a huge challenge for Polish entrepreneurs. It means making first steps in the most powerful economy in the world where headquarters of many global giants are located, as entities from a country belonging to the group of latecomers among direct investors abroad. Huge competition and saturation of the American market lead to a question: how are Polish companies dealing in this economic reality and where do they find determinants for their growth? In an attempt to explain this research problem, this paper focuses on the internal factors determining the development of Polish entities in the USA, considering the character of their activity, i.e. splitting the analysed group into companies operating in traditional industries and in new technologies.

\section{Literature review}

Many theories explaining foreign direct investment emphasise the role of company assets in their international expansion. S.H. Hymer, the author of the ownership advantages theory, was a pioneer in this field. In his opinion, the prerequisite for starting investment activity abroad is to have certain specific advantages over the companies in the country of location, referred to as the ownership advantages. These advantages may relate to different fields of activity of the company, e.g. they may concern applied technology, methods of management, marketing or access to financial resources (see more: Karaszewski, 2004; Kuzel, 2018). J.H. Dunning also believed that ownership advantages are required to start business activity abroad - either through direct foreign investment, export or management contracts (Dunning, 1981). Dunning's considerations on ownership advantages changed with the time. In one of his last papers, co-authored with S.M. Lundan, he presented specific ownership advantages of an internationalising company as a synthesis of three groups of factors: advantages due to assets owned (particularly intangible assets), advantages due to company's capability to coordinate geographically dispersed activities and to diversify the risk and finally institutional advantages, encompassing formal and informal standards and values regulating activities in all entities of an international company (Dunning and Lundan, 2010). According to the said concept - referred to as the eclectic paradigm or OLI paradigm - a company undertakes a foreign direct investment when the benefits 
INTERNAL DEVELOPMENT DETERMINANTS

Magdalena Kuczmarska of individual use of their ownership advantages are greater than the benefits of selling the rights to use them to a foreign enterprise. It means that the company has internationalisation-specific advantages and the country of location will enable the investor to achieve greater benefits from specific ownership advantages than the home country of the company, so location advantages will occur (Eden and Dai, 2010).

The ownership advantages highlighted in the cited concepts explaining international expansion may be associated with unique assets of companies, that could become the grounds for shaping competitive advantage on foreign markets (Wang et al., 2011). Therefore, the starting point for considerations on business internationalisation are the capabilities of a company, determined by its assets (Godziszewski, 2001). However, according to the resource-based view, these assets must be valuable, rare, imperfectly imitable and imperfectly substitutable (Barney, 1991). A number of scientific papers confirm that possession of assets with features like technological knowledge or skills in marketing and management, has positive effect on the degree of internationalisation of a company (Yeoh and Roth, 1999; Trevino and Grosse, 2002; Tseng et al., 2007; Hitt et al., 2006; Lau et al., 2010; Wang et al., 2011; Gaur et al., 2014). They seem particularly important when undertaking foreign direct investment in highly developed countries, like the USA, characterised by high market saturation and strong competition. According to Chen and Chen (1998), due to the fact that US market is well-structured and highly specialised, only firms with powerful and abundant internal resources are qualified to enter.

Since these resources are deemed the domain of international companies from the developed countries, it is often emphasised in the subject literature that FDI of multinational enterprises from emerging countries or from developing countries cannot be explained only in the context of benefits from using traditional ownership advantages, such as proprietary technology, financial capital, brands, and experienced management (Goldstein, 2007; Bonaglia et. al., 2007; Caccia, Baleix, 2018). Instead, it is highlighted that these companies have other, non-traditional advantages related with the country of origin, such as better political capabilities, or superior abilities to operate in harsh institutional environment in other developing countries (Cuervo-Cazurra and Genc, 2008), access to natural resources, cheap labour and cheap capital (see more: Aharoni, 2014). These resources, particularly valuable in case of operation in other developing countries, seem insufficient to build competitive advantage in developed countries. Consequently, in scientific papers attempting to explain the foreign expansion of companies from developing countries in developed countries in form of FDI, emphasis is put on the fact that investment of this type are often motivated by the willingness to acquire strategic assets that would help to build firm-specific advantages and catch up with competitors on the 
developed markets (Dunning and Lundan, 2008; Kedia et. al., 2012; Yoo and Reimann, 2017).

In view of the considerations on the ownership advantages of companies originating from economies characterised with various level of development, Polish international companies are quite interesting. On one hand, Poland mainly due to the membership in the European Union - is considered a developed economy (UNCTAD, 2019), but in other classifications it belongs to emerging markets and developing economies (IMF, 2018). In the studies on internationalisation, this country is usually placed in the latter category (Obłój and Wąsowska, 2012; Cuervo-Cazurra, 2012; Karaszewski et al., 2014; Kuzel, 2018), but it is often emphasised that it belongs to so-called mid-range emerging economies (which are positioned between traditional emerging economies and newly developed economies) (Hoskisson et al., 2013; Trapczyński and Banalieva, 2016; Trąpczyński and Gorynia, 2017). There are, however, other studies that include Poland in the group of developed countries (Yoo and Reimann, 2017). A survey conducted among Polish international companies indicated that their FDI - just as the investments of firms from developed countries - were motivated, among others, by the willingness to use the resources developed on the home market (Jaworek, 2008; Jaworek, 2013; Gorynia et. al., 2015), and much less frequently by the need to find resources on a foreign market (Jaworek, 2008; Jaworek, 2013; Kowalewski and Radło, 2014). The outcomes of a research conducted by Gorynia et al. (2015) also indicated that the said resources were mainly connected with entrepreneurial and managerial skills, and the ability to develop and leverage business networks abroad. The surveyed enterprises emphasised that even if their investments were focused on strategic asset seeking, undertaking them required possession of complementary assets developed in the home country, that would be further used and extended on the foreign market. On the other hand, the study conducted by Trapczyński (2015) demonstrated that Polish companies claimed that ability to develop new products and the ability to adapt the product offering to market requirements were among their major firmspecific resources, followed by managerial skills and technological capabilities. However, these intangible assets were rather positively evaluated in relation to the capabilities of their key competitors.

Considering the role of internal resources of companies in their foreign expansion, in particular on the markets in developed countries, this paper focuses on identifying the major development determinants of companies with share of Polish capital in the USA. The analysed resources have been split into four categories: production and services, marketing, organisation and management and also finance. The findings are presented with reference to the singularity of the analysed companies, split into two groups: companies operating in the area of new technologies and enterprises operating in traditional industries. 
INTERNAL DEVELOPMENT DETERMINANTS

Magdalena Kuczmarska

\section{Methodology}

The results presented in this paper come from a survey conducted between 2016 and 2017. It covered Polish enterprises which had undertaken direct investment in the United States. The identification of the surveyed population was made possible thanks to the Trade and Investment Promotion Section of the Polish Embassy in Washington providing a database of Polish companies that had registered their operations in the USA by March 2016. The database was created based on own insightful knowledge of the Embassy and on public information. It contained a list of 82 Polish investors, who had created a total of 92 direct investment entities in the USA. It must be emphasised that the number of enterprises obtained this way differed only slightly from the full population of entities with Polish capital in the USA published by Statistics Poland in the same period. According to their data, Polish enterprises had 119 foreign entities in the USA at the end of 2015 (Statistics Poland, 2016), i.e. 27 entities more than indicated by data collected by the Embassy.

Before commencing research proceedings, the database had been verified, allowing elimination of economically inactive entities. As a result, 76 Polish enterprises were invited to participate in the study, which gave a total of 84 foreign entities in the USA.

The research was started in September 2016 by sending by post and e-mail a standardised questionnaire to the companies covered by the study. 19 questionnaires were filled out correctly, which meant a return rate of $25 \%$. It must be pointed out that survey respondents were representatives of the management staff, in both parent companies and direct investment companies in the USA, including primarily presidents, managing directors as well as directors of finance, marketing and public relations departments.

The largest group of respondents were entities that did business mainly in the services sector (79.0\% of the total number of enterprises), and the largest number of entities in this group did business under the "Information and Communication" NACE section (47.4\% of respondents), and then in trade and in professional, scientific and technical fields (respectively $15.8 \%$ of respondents). For other enterprises $(21.0 \%$ ), production was the dominating sector, within which $10.5 \%$ of respondents did business within the "Industrial Processing" and "Mining and Quarrying" sections respectively.

The results were presented taking into account the singularities of the surveyed entities, splitting them into two groups, namely enterprises doing business in the area of new technologies and entities operating in traditional industries. The first group comprised entities doing business within two different sections: "Information and Communication" and "Professional, Scientific and Technical activities". The second group included entities operating in the following sections: "Mining and Quarrying", "Industrial Processing" and "Wholesale and Retail 
Trade; Motor Vehicle Repair". The share of the respondents in each group was $63.2 \%$ and $36.8 \%$ respectively.

The questions in the research questionnaire regarding the individual factors' impact on the development of Polish direct investment companies in the USA were closed-ended questions. The respondents determined the impact of individual factors using a seven-point scale with a range from -3 to +3 , where: -3 meant a strong negative impact, $-2-$ a negative impact, $-1-$ a slightly negative impact, $0-$ no impact (neutral factor), $+1-$ a slightly positive impact, $+2-$ a positive impact, and $+3-$ a strong positive impact. The impact strength of individual variables was determined using a weighted arithmetic mean, hereinafter referred to as the impact indicator (i). The level of an index value determined the position of individual indicators in the value hierarchy.

\section{Results}

The surveyed companies were asked to evaluate 16 potential internal development determinants for entities with share of Polish capital in the USA, grouped in four categories: production/services, marketing, organisation and management as well as finance. It must be considered that the grounds of the analysed determinants included the resources brought by parent companies to their subsidiaries, further developed on the foreign market. Impact assessment comprised the seven following dimensions: strong positive, positive, slightly positive, no impact, slightly negative, negative, strong negative.

The results of the survey demonstrated that ratings of potential internal development determinants were not much different between the groups of the surveyed firms. The enterprises operating in the new technologies defined the sources of their development mainly in production/services factors, i.e. in applied technologies (first rank, $\mathrm{i}=2.25$ ), product/service innovation (second rank, $\mathrm{i}=$ 2.09 ), organisation of production/service processes and employee qualifications (third rank, $\mathrm{i}=2.00$ ) (table 1). Other internal development determinants indicated by the surveyed companies included leadership ( $4^{\text {th }}$ rank, $\left.i=1.83\right)$, product service/ quality $\left(5^{\text {th }}\right.$ rank, $\left.i=1.82\right)$, organisation culture $\left(6^{\text {th }}\right.$ rank, $\left.i=1.67\right)$, management team commitment $\left(7^{\text {th }}\right.$ rank, $\left.i=1.64\right)$ and management team competences $\left(8^{\text {th }}\right.$ rank, $i=1.58)$. In the opinion of the surveyed companies from the new technology sector, marketing and finance factors had much smaller impact on their growth: company image ( $9^{\text {th }}$ rank, $\left.i=1.33\right)$, company financial capital $\left(10^{\text {th }}\right.$ rank, $\left.i=1.30\right)$, qualifications of employees employed in marketing $\left(12^{\text {th }}\right.$ rank, $\left.i=1.00\right)$, marketing activity $\left(13^{\text {th }}\right.$ rank, $\left.i=0.92\right)$ and finance team qualifications $\left(15^{\text {th }}\right.$ rank, $\left.i=0.45\right)$. Beside that, these companies attributed slight positive impact to such factors as up-to-date equipment $\left(11^{\text {th }}\right.$ rank, $\left.i=1.09\right)$ and employee attitudes $\left(14^{\text {th }}\right.$ rank, $i=$ $0.82)$. 
INTERNAL DEVELOPMENT DETERMINANTS

Magdalena Kuczmarska

Table 1. Internal development determinants of Polish enterprises in the United States (survey results)

Guidance notes: impact indicator (i) taking the value from -3 to 3 .

Source: own study on the basis of survey results.
Unlike companies representing the new technology sector, entities operating in traditional industries perceived major growth determinants in the field of entrepreneurial and managerial skills, rather than in production and servicesrelated factors. The major internal growth determinants listed by these companies included leadership ( $1^{\text {st }}$ rank, $\left.i=2.29\right)$, management team competences and organisation culture ( $2^{\text {nd }}$ rank, $\left.\mathrm{i}=1.86\right)$, followed by organisation of production/ service process $\left(3^{\text {rd }}\right.$ rank, $\left.i=1.71\right)$, company financial capital $\left(4^{\text {th }}\right.$ rank, $\left.i=1.67\right)$, product/service innovation $\left(5^{\text {th }}\right.$ rank, $\left.i=1.57\right)$ and applied technologies $\left(6^{\text {th }}\right.$ rank, $\mathrm{i}=1.50)$. Among the factors that had less positive impact on business development in traditional industries were management team commitment $\left(7^{\text {th }}\right.$ rank, $\left.i=1.29\right)$, up-to-date equipment ( $\left.8^{\text {th }} \mathrm{rank}, \mathrm{i}=1.14\right)$, product/service quality $\left(9^{\text {th }} \mathrm{rank}, \mathrm{i}=\right.$ $1.00)$, qualifications of employees employed in marketing $\left(10^{\text {th }}\right.$ rank, $\left.i=0.86\right)$, marketing activity $\left(11^{\text {th }}\right.$ rank, $\left.\mathrm{i}=0.83\right)$, employee qualifications and attitudes $\left(12^{\text {th }}\right.$ rank, $i=0.71)$ and finance team qualifications $\left(13^{\text {th }}\right.$ rank, $\left.i=0.14\right)$.

\begin{tabular}{|c|c|c|c|c|}
\hline \multirow{3}{*}{ Internal development determinants } & \multicolumn{4}{|c|}{ Enterprises } \\
\hline & \multicolumn{2}{|c|}{ New technologies } & \multicolumn{2}{|c|}{ Traditional industries } \\
\hline & $\begin{array}{l}\text { Impact } \\
\text { indicator }\end{array}$ & Position & $\begin{array}{l}\text { Impact } \\
\text { indicator }\end{array}$ & Position \\
\hline \multicolumn{5}{|c|}{ I. Production/services } \\
\hline applied technologies & 2.25 & 1 & 1.50 & 6 \\
\hline organisation of production/service processes & 2.00 & 3 & 1.71 & 3 \\
\hline product/service quality & 1.82 & 5 & 1.00 & 9 \\
\hline product/service innovation & 2.09 & 2 & 1.57 & 5 \\
\hline employee qualifications & 2.00 & 3 & 0.71 & 12 \\
\hline employee attitudes & 0.82 & 14 & 0.71 & 12 \\
\hline up-to-date equipment & 1.09 & 11 & 1.14 & 8 \\
\hline \multicolumn{5}{|c|}{ II. Marketing } \\
\hline marketing activity & 0.92 & 13 & 0.83 & 11 \\
\hline $\begin{array}{l}\text { qualifications of employees employed in } \\
\text { marketing }\end{array}$ & 1.00 & 12 & 0.86 & 10 \\
\hline company image & 1.33 & 9 & 1.14 & 9 \\
\hline \multicolumn{5}{|c|}{ III. Organisation and management } \\
\hline management team competences & 1.58 & 8 & 1.86 & 2 \\
\hline leadership & 1.83 & 4 & 2.29 & 1 \\
\hline organisation culture & 1.67 & 6 & 1.86 & 2 \\
\hline management team commitment & 1.64 & 7 & 1.29 & 7 \\
\hline \multicolumn{5}{|c|}{ IV. Finance } \\
\hline company financial capital & 1.30 & 10 & 1.67 & 4 \\
\hline finance team qualifications & 0.45 & 15 & 0.14 & 13 \\
\hline
\end{tabular}


Slight differences in the evaluation of individual factors confirm the singularity of the analysed companies. Ownership advantages of enterprises from the new technologies, that were running their business mainly in the innovative ecosystem of the Silicon Valley, naturally had to be connected with applied technologies and innovation of offered products. As far as companies representing traditional industries are concerned, having more extensive experience in operating on foreign markets, they associated major growth determinants with entrepreneurial and managerial skills. However, is should be emphasised that regardless of the major indications, both groups had a positive view of the factors related with production/ services as well as organisation and management. The singularity of the surveyed enterprises also affected their assessment of significance of financial resources. For large companies operating in traditional industries, financial resources were an important development determinant on the American market, while companies representing the new technology sector listed it on relatively lower ranks. What is interesting, irrespective of the surveyed group of companies, respondents mentioned marketing factors as relatively less significant. This evaluation of marketing skills in relation to other firm-specific resources of Polish companies was also confirmed in the research conducted by P. Trąpczyński (2015).

Generally, presented results of the survey demonstrate that Polish companies had a positive image of all internal development determinants, thus none of the listed assets was identified as a destimulant of development on the American market. However, the strength of impact of individual factors was moderate (most indicated a positive effect or slightly positive effect).

\section{Conclusions}

Polish companies are more confident in developing through foreign direct investment. They decide to allocate their capital not only in geographically and culturally close European markets, but also undertake investment in more distant countries, offering significant benefits of using ownership advantages possessed by the company.

The most popular non-European country of Polish capital allocation is the USA. That market, mainly due to its size and high specialisation is an attractive location, both for companies operating in traditional industries, willing to improve their international competitiveness, as well as for small technological companies, intending to develop their products in innovative ecosystems, such as the Silicon Valley. This attractiveness of the American market is appealing for investors from all over the world, making it extremely difficult to compete.

Both the research results and the very fact of involvement in foreign investment in such competitive environment demonstrate that Polish companies are aware of the strength of their assets. Irrespective of the analysed group of entities (companies operating in traditional industries or new technology 
INTERNAL DEVELOPMENT DETERMINANTS

Magdalena Kuczmarska sector), respondents associated major determinants of growth on the American market with factors mainly belonging to two categories: production/services and organisation/management. Companies from the new technologies indicated applied technologies, product/service innovation, organisation of production/ service processes, employee qualifications, leadership as well as product/service quality as the major internal development determinants. According to the answers given by companies operating in traditional industries, the main factors of development on the US market were leadership, management team competences, organisation culture, company, financial capital and product/service innovation.

It implies that the grounds for the Polish companies' expansion to the USA is willingness to use and improve valuable resources previously developed on the home market, such as proprietary technologies, innovative products and managerial skills. Although Polish companies do not have as large financial resources or marketing skills as major international corporations, the value of their assets is so significant that they can have considerable impact on competitive advantage of those entities in an international scale.

\section{References}

Aharoni, Y. (2014), "Theoretical debates on multinationals from emerging economies", in: Cuervo-Cazurra, A., Ramamurti, R. (Eds.), Understanding multinationals from emerging markets, Cambridge University Press, Cambridge, pp. 15-30.

Barney, J. (1991), "Firm Resources and Sustained Competitive Advantage", Journal of Management, Vol. 17 No. 1, pp. 99-120.

Bonaglia, F., Goldstein, A., Mathews, J.A. (2007), "Accelerated internationalization by emerging markets' multinationals: The case of the white goods sector", Journal of World Business, Vol. 42 No. 4, pp. 369-383.

Caccia, F.C., Baleix, J.M. (2018), "FDI from emerging countries: motivations and impacts", Revista de Economia Mundial, Vol. 50, pp. 65-82.

Chen, H., Chen., T.-J. (1998), "Network Linkages and Location Choice in Foreign Direct Investment", Journal of International Business Studies, Vol. 29 No. 3, pp. 445-467.

Cuervo-Cazurra, A. (2012), "Extending theory by analyzing developing country multinational companies: solving the goldilocks debate", Global Strategy Journal, Vol. 2 No. 3, pp. 153-167.

Cuervo-Cazurra, A., Genc, M. (2008), "Transforming disadvantages into advantages: developing-country MNEs in the least developed countries", Journal of International Business Studies, Vol. 39 No. 6, pp. 957-979.

Cuervo-Cazurra, A., Ramamurti, R. (2013), Understanding multinationals from emerging markets, Cambridge University Press, Cambridge.

Dunning, J.H. (1981), "Explaining the International Direct Investment Position of Countries: Towards a Dynamic or Developmental Approach", Weltwirtschaftliches Archiv, Vol. 117 No. 1, p. 30-64. 
Dunning, J.H., Lundan, S.M. (2008), Multinational Enterprises and the Global Economy, Edward Elgar Publishing, Northampton.

Dunning, J.H., Lundan, S.M. (2010), "The institutional origins of dynamic capabilities in multinational enterprises", Industrial and Corporate Change, Vol. 19 No. 4, pp. $1225-1246$.

Eden, L., Dai, L. (2010), "Rethinking the O in Dunning's OLI/Eclectic Paradigm”, Multinational Business Review, Vol. 18 No. 2, pp. 13-34.

Gaur, A.S., Kumar, V., Singh D. (2014), "Institutions, resources, and internationalization of emerging economy firms", Journal of World Business, Vol. 49 No. 1, pp. 12-20.

Godziszewski, B. (2001), Zasobowe uwarunkowania strategii przedsiębiorstwa [Resource conditions in the company's strategy], Wydawnictwo Naukowe Uniwersytetu Mikołaja Kopernika, Toruń.

Goldstein, A. (2007), Multinational companies from emerging economies: composition, conceptualization and direction in the global economy, Palgrave Macmillian, Basingstoke.

Gorynia, M., Nowak, J., Trąpczyński, P., Wolniak, R. (2015), “Outward FDI of Polish firms: The role of motives, entry modes and location factors", Journal for East European Management Studies, Vol. 20 No. 3, pp. 328-359.

Hitt, M.A., Bierman, L., Uhlenbruck, K., Shimizu, K. (2006), “The Importance of Resources in the Internationalization of Professional Service Firms: The Good, the Bad, and the Ugly", The Academy of Management Journal, Vol. 49 No. 6, pp. 1137-1157.

Hoskisson, R.E., Wright, M., Filatotchev, I., Peng, M.W. (2013), "Emerging Multinationals from Mid-Range Economies: The Influence of Institutions and Factors Markets", Journal of Management Studies, Vol. 50 No.7, pp. 1295-1321.

IMF (2018), "World Economic Outlook Database", available at: https://www.imf.org/ external/pubs/ft/weo/2018/02/weodata/index.aspx (accessed 7 September 2018).

Jaworek, M. (2008), ,Stymulanty i destymulanty podejmowania inwestycji bezpośrednich za granicą przez polskie przedsiębiorstwa” [,Incentives and Disincentives for Undertaking Foreign Direct Investment by Polish Companies"], in: Karaszewski, W. (Ed.), Bezpośrednie inwestycje zagraniczne polskich przedsiębiorstw [Foreign Direct Investment by Polish Companies], Wydawnictwo „Dom Organizatora”, Toruń.

Jaworek, M. (2013), "Stymulanty i destymulanty aktywności inwestycyjnej polskich przedsiębiorstw za granicą” [,Investment Incentives and Disincentives among Polish Companies Abroad"], in: Karaszewski, W. (Ed.), Aktywność inwestycyjna polskich przedsiębiorstw za granica - czynniki i skutki [Investment Activity of Polish Companies abroad - factors and effects], PWE, Warszawa.

Karaszewski, W. (2004), Bezpośrednie inwestycje zagraniczne. Polska na tle świata [Foreign Direct Investment. Poland on the Background of the World], Wydawnictwo „Dom Organizatora”, Toruń.

Karaszewski, W., Jaworek, M., Kuzel, M., Szałucka, M., Szóstek, A. (2014), Foreign Direct Investment by Polish Companies, Wydawnictwo Naukowe Uniwersytetu Mikołaja Kopernika, Toruń.

Kedia, B., Gaffney, N., Clampit, J. (2012), "EMNEs and knowledge-seeking FDI”, Management International Review, Vol. 52 No. 2, pp. 155-173. 
INTERNAL DEVELOPMENT DETERMINANTS

Magdalena Kuczmarska
Kowalewski, O., Radło, M.-J. (2014), "Determinants of foreign direct investment and entry modes of Polish multinational enterprises: A new perspective on internationalization", Communist and Post-Communist Studies, Vol. 47 No. 3-4, pp. 365-374.

Kuzel, M. (2018), Kapitat intelektualny organizacji w procesie internacjonalizacji polskich przedsiębiorstw - inwestorów zagranicznych [An Organisation's Intellectual Capital in the Process of Internationalisation of Polish Companies - Foreign Investors], Wydawnictwo Naukowe Uniwersytetu Mikołaja Kopernika, Toruń.

Lau, C.-M., Ngo, H.-Y., Yiu, D.W. (2010), "Internationalization and organizational resources of Chinese firm", Chinese Management Studies, Vol. 4 No. 3, pp. 258272.

Makino, S., Lau, C.-M., Yeh, R.-S. (2002), “Asset-exploitation Versus Asset-Seeking: Implications for Location Choice of Foreign Direct Investment from Newly Industrialized Economies", Journal of International Business Studies, Vol. 33 No. 3, pp. 403-421.

Obłój, K., Wąsowska, A. (2012), "Location Determinants of Polish Outward FDI and the (limited) Impact of the Global Crisis", in: Marinov, M. (Ed.), Emerging economies and their firms in the global crisis, Palgrave Macmillan, London.

Pietrasieński, P. (2014), Aktywizowanie internacjonalizacji przedsiębiorstw - dobre praktyki rządów, strategie wsparcia w Dolinie Krzemowej [Activating Internationalisation of Enterprises - Good Government Practices, Support Strategies in the Silicon Valley], PWE, Warszawa.

Statistics Poland (2016), Activity of enterprises having foreign entities in the years 2008-2014, Warsaw.

Statistics Poland (2019), Activity of enterprises having foreign entities in 2017, Warsaw.

Trąpczyński, P. (2015), Foreign direct investment strategies and performance in the internationalization of Polish companies, Difin, Warsaw.

Trąpczyński, P., Banalieva, E.R. (2016), "Institutional difference, organizational experience, and foreign affiliate performance: Evidence from Polish firms", Journal of World Business, Vol. 51 No. 5, pp. 826-842.

Trąpczyński, P., Gorynia, M. (2017), “A double-edged sword? The moderating effects of control on firm capabilities and institutional distance in explaining foreign affiliate performance", International Business Review, Vol. 26 No. 4, pp. 697-709.

Trevino, L.J., Grosse, R. (2002), "An analysis of firm-specific resources and foreign direct investment in the United States", International Business Review, Vol. 11 No. 4 , pp. 421-452.

Tseng, C.-H., Tansuhaj, P., Hallagan, W., McCullough, J. (2007), "Effects of firm resources on growth in multinationality", Journal of International Business Studies, Vol. 38 No. 6, pp. 961-974.

UNCTAD (2019), World Investment Report 2019: Special Economic Zones 2019, Geneva. Wang, C., Hong, J., Kafouros, M., Boateng, A. (2011), "What drives outward FDI of Chinese firms? Testing the explanatory power of three theoretical framework", International Business Review, Vol. 21 No. 3, pp. 425-438.

Yeoh, P.-L., Roth, K. (1999), “An Empirical Analysis of Sustained Advantage in the 
U.S. Pharmaceutical Industry: Impact of Firm Resources and Capabilities", Strategic Management Journal, Vol. 20 No. 7, pp. 637-653.

Yoo, D., Reimann, F. (2017), "Internationalization of Developing Country Firms into Developed Countries: The Role of Host Country Knowledge-Based Assets and IPR Protection in FDI Location Choice", Journal of International Management, Vol. 23 DETERMINANTS

No. 3, pp. 242-254.

Magdalena Kuczmarska 